"Investigate the level of disclosure of emissions of the top ten manufacturing companies in South Africa"

\begin{tabular}{ll} 
AUTHORS & $\begin{array}{l}\text { Anet M. Smit } \\
\text { Johanna Magdalena van Zyl }\end{array}$ \\
\hline ARTICLE INFO & $\begin{array}{l}\text { Anet M. Smit and Johanna Magdalena van Zyl (2016). Investigate the level of } \\
\text { disclosure of emissions of the top ten manufacturing companies in South Africa. } \\
\text { Environmental Economics, } 7(1), 76-86 . \text { doi: } 10.21511 / \text { ee.07(1).2016.10 }\end{array}$ \\
\hline DOI & http://dx.doi.org/10.21511/ee.07(1).2016.10 \\
\hline RELEASED ON & Thursday, 24 March 2016 \\
\hline JOURNAL & "Environmental Economics" \\
\hline FOUNDER & LLC "Consulting Publishing Company "Business Perspectives"
\end{tabular}

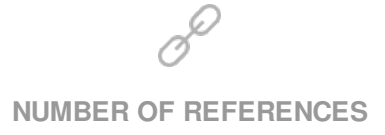

0

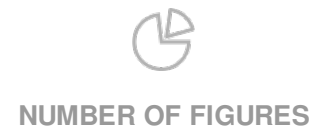

0

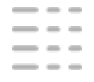

NUMBER OF TABLES

0

(C) The author(s) 2022. This publication is an open access article. 
Anet M. Smit (South Africa), Johanna Magdalena van Zyl (South Africa)

\title{
Investigate the level of disclosure of emissions of the top ten manufacturing companies in South Africa
}

\begin{abstract}
Throughout the world, countries and companies are directing their attention towards actions to protect the planet. An important focus area during various initiatives is the aim to stabilize greenhouse gas concentrations at a level that would prevent dangerous anthropogenic interference with the climatic system. Various targets are set by governments to reduce greenhouse gas emissions and the South African Government is, among others, investigating a carbon tax policy to facilitate their transition to a greener economy. This paper analyzes the sustainability reports of the top ten manufacturing companies listed on the Johannesburg Stock Exchange (JSE) and the disclosures of emissions were evaluated against a checklist that was developed through a literature review comprising various sources.

From the results of the research, it is evident that all the companies reviewed are aware of the importance of emissions disclosure and the impact that emissions have on climate change. Companies, in general, adhere more to the qualitative, narrative type of requirements than to the more quantitative, performance-related reporting of emissions. In this study the reporting of the companies specifically on Scope 3 emissions were inadequate. More attention should be given to measure performance and to improve their systems to quantify data.
\end{abstract}

Keywords: carbon tax, environmental policy, environmental disclosure, integrated reporting, Carbon Disclosure Project, greenhouse gas.

JEL Classification: Q56, M41, P42.

\section{Introduction}

More than 150 countries signed the United Nations Framework Convention on Climate Change (FCCC) in 1992 aiming to protect the climate by stabilizing greenhouse gas concentrations at a level that would prevent dangerous anthropogenic interference of the climatic system (Kim and Worrel, 2002). During the second and third conferences, further actions were identified and targets were set to reduce emissions of greenhouse gases of which $\mathrm{CO}_{2}$ is the most significant (Kim andWorrel, 2002). During the latest Session of the Conference of the Parties to the United Nations Framework Convention on Climate Change (COP21/CMP11) held in December 2015 in France, the main goal once again was to reach a new international agreement on climate to limit global warming to less than $2^{\circ}$ Celsius. The South African Government published their Carbon Tax Policy Paper on 2 May 2013 with the aim of reducing greenhouse gas emissions (GHG) and facilitates the transition to a greener economy. The carbon tax will be applicable to companies in the electricity, petroleum (coal/gas to liquid), petroleum (oil refinery), iron and steel, cement, glass and ceramics, chemicals, pulp and paper, sugar, and fugitive emissions (Jeffrey, 2013). The policy indicates that carbon will be taxed at R120 per tonne $\mathrm{CO}_{2}$, but a fairly complex structure is created on how exactly the process will be handled (Jeffrey, 2013). This policy was scheduled for implementation

(C) Anet M. Smit, Johanna Magdalena van Zyl, 2016

Anet M. Smit, Ph.D., Associate Professor, North-West University, NWU Potchefstroom Business School, North-West University, Potchefstroom, South Africa.

Johanna Magdalena van Zyl, MBA Student, NWU Potchefstroom Business School, North-West University, Potchefstroom, South Africa. in 2015, but has been postponed to 2016 (Klausbruckner, Annegarn, Henneman and Rafaj, 2016).

According to Kim and Worrel (2002), the global manufacturing industry emits up to 43 percent of global $\mathrm{CO}_{2}$ emissions. In 2004 South Africa emitted $440 \mathrm{Mt} \mathrm{CO}_{2}$ eq., which was about $1 \%$ of global emissions and this has already risen to $1.4 \%$ in 2010 (Klausbruckner, Annegarn, Henneman and Rafaj, 2016). At this stage South Africa is regarded as one of the world's most carbon intensive economies. According to the Carbon Disclosure Project (CDP, 2010), companies will ensure they remain in business by continuously identifying risks and opportunities by increasing their resilience and making climate change and the measuring, verifying and reporting of the GHG emissions part of their core business strategy.

With the looming implementation of carbon tax in South Africa, companies should adhere to sustainability reporting as many investors raised concerns regarding the sustainability of their investments should carbon tax be implemented. The proper disclosure of current carbon emissions can make a valuable contribution to investors not only in the estimation of the possible impact of carbon tax, but also add value to their investment decision-making process.

South Africa can be classified as both a contributor to and victim of global climate change and is ranked among the top 20 countries measured by absolute carbon dioxide $\left(\mathrm{CO}_{2}\right)$ emissions, as the country emits more greenhouse gases (GHGs) than all the other SubSaharan African countries combined, mainly because of its carbon-intensive economic sectors (Mbadlanyana, 2013). Proper disclosure of carbon emissions is therefore important to equip shareholders and possible 
investors with enough information to maintain the trust and confidence in the performance of the company and its sustainability.

Carbon tax will, however, also impose substantial adjustment costs on the economy, including reduced export competitiveness, job losses and higher energy prices (Alton, Arndt, Davies, Hartley, Makrelov, Thurlow and Ubogu, 2013). Carbon taxes will reduce national welfare, but are regarded as more efficient than other tax instruments on energy use or pollution, and in South Africa, the welfare impact is more affected by institutional distortions than tax distortions (Devarajan, Go, Robinson and Thierfelder, 2011). The introduction of carbon tax in South Africa will, however, result in increased prices and will place the country in a considerable competitive disadvantage (Jeffrey, 2013).

The Carbon Disclosure Project (CDP) is a non-profit organization that was established in 2000, situated in the United Kingdom (UK), and operates the only global climate reporting system. The objective of the project is to raise overall awareness for both corporates and investors and the goal, as stated on its website, is "to create a lasting relationship between shareholders and corporations regarding the implications for shareholder value and commercial operations presented by climate change" (CDP, 2010).

Despite some uncertainty regarding carbon disclosure, the measurement and reporting of carbon emissions at the product, facility and organization levels display considerable momentum and this growth is the result of mainly three core drivers, namely: regulatory compliance, pressure from non-governmental organizations and managerial information systems intended to facilitate participation in carbon markets, and lastly reduced energy costs and management of reputational risk (Know-Hayes and Levy, 2011). Continuous voluntary improvement in the levels of disclosure across all indicators as reported in the climate change report mainly attributed to an increased commitment to more sustainable business (CDP, 2013).

Industries worldwide are becoming progressively more aware of the social and environmental liabilities pertaining to their operations and products as these liabilities have financial effects associated with them (De Beer and Friend, 2006). A corporation's environmental performance and the public disclosure of that performance are the elements of corporate environmental accountability and jointly affect the corporation's profitability and the value of its common equity (Al-Tuwaijri, Christensen and Hughes, 2004).

\section{Literature review}

1.1. Introduction. Companies all over the world want to make their operations sustainable, and ex- pectations that long-term profitability goes hand-inhand with social justice and protecting the environment are gaining ground, according to the Global Reporting Initiative (GRI) (2013). In South Africa, sustainability has been addressed in the King III Report in terms of the triple bottom-line concept of economic, social and environmental sustainability (Smith and Perks, 2010). Integrated reporting puts the financial results of a company in perspective by reporting on how a company has both positively and negatively impacted on the economic life of the community in which it operated during the year under review; it also indicates how the company intends to enhance those positive aspects and eradicate the negative aspects in the year ahead (Eccles and Saltzman, 2011). To ensure a company maintains or improves the trust and confidence of the shareholders, it is important that they adhere to integrated reporting and simultaneously confirm the company's values, ethics and governance.

The first national attempt to enforce integrated reporting across all listed companies was introduced in 2010 by the Johannesburg Stock Exchange (JSE) when they mandated integrated reporting through its listing requirements via compliance with the King III Report of 2009 (Solomon and Maroun, 2012).

According to the Integrated Reporting Committee (IRC) (2011), an integrated report is the organization's primary report and the overarching objective is to enable stakeholders to assess the ability of an organization to create and sustain value over the short-, medium- and long-term. The integrated report should ultimately replace all other forms of corporate reporting and will represent the primary vehicle for communicating with shareholders and other stakeholders (Solomon and Maroun, 2012). Comparability, consistency, verifiability, timeliness, understandability and clarity are key principles to determine the quality of the reported information (IRC, 2011, p. 10), while the crucial elements determining the content of integrated reports are materiality, a focus on risk, risk management, strategy and the need for forward-looking information (Solomon et al., 2012).

Sustainability reporting is an intrinsic element of integrated reporting as it considers the relevance of sustainability and addresses sustainability priorities and key topics, focusing on the impact of sustainability trends, risk and opportunities on the longterm prospects and financial performance of the organization (GRI, 2013). Sustainability reporting is therefore fundamental to an organization's integrated thinking and reporting process in providing input into identifying material issues, strategic objectives and the assessment of the ability to achieve such objectives (GRI, 2013). 
1.2. Guidelines as per the latest Global Reporting Initiative. When using the guidelines as given by GRI, organizations firstly need to decide the most suitable 'in accordance' option. Guidelines are provided for a core or a comprehensive option and any option can be applied by all organizations irrespective of their size, sector or location as both options focus on the process of identifying the organization's significant economic, environmental and social impacts.

The core option contains the essential elements of a sustainability report and provides the background against which an organization communicates the impacts of its economic, environmental and social governance performance (GRI, 2013). The comprehensive option builds on the core option by requiring additional standard disclosures of the organization's strategy and analysis, governance, ethics and integrity, and organizations are required to communicate their performance more extensively by reporting all indicators related to the identified material aspects (GRI, 2013). The type of option does not have any relation to the quality of the report or to the performance of the organization; therefore, organizations need to choose the option that best meets its reporting needs and those of its stakeholders regarding the information they require (GRI, 2013).

The guidelines provided by the GRI further include recommendations regarding standard disclosures. Standard disclosures consist of two different types, namely general standard disclosures and specific standard disclosures. General standard disclosures are applicable to all organizations preparing sustainability reports and, depending on the 'in accordance' option, organizations have to identify the required general standard disclosures to be reported. Specific standard disclosure is the disclosure of management approach and indicators. Emissions are classified as one of the aspects under the environmental category that is part of the specific standard disclosures and includes guidelines regarding greenhouse gas (GHG) emissions as well as ozone-depleting substances, $\mathrm{NO}_{\mathrm{X}}, \mathrm{SO}_{\mathrm{X}}$ and other significant air emissions (GRI, 2013). The purpose of this paper is to focus on greenhouse gas emissions and the guidelines provided by the GRI regarding the reporting of greenhouse gas emissions. Table 1 provides a summary of the guidelines focusing only on greenhouse gas emissions.

Table 1. Guidelines for emissions disclosure as per GRI

\begin{tabular}{|c|c|c|c|}
\hline $\begin{array}{l}\text { Guidelines for: } \\
\quad \text { Direct greenhouse gas emissions (Scope 1) } \\
\quad \text { Energy indirect greenhouse gas emissions (Scope 2) } \\
\text { Other indirect greenhouse gas emissions (Scope 3) }\end{array}$ & 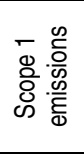 & 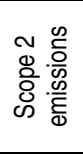 & 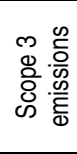 \\
\hline $\begin{array}{l}\text { Report gross direct (Scope 1) } \mathrm{GHG} \text { emissions in metric tons of } \mathrm{CO}_{2} \text { equivalent, independent of any } \mathrm{GHG} \text { trades, such as } \\
\text { purchase, sales or transfers of offsets or allowances }\end{array}$ & $\mathrm{X}$ & & \\
\hline $\begin{array}{l}\text { Report gross energy indirect } \mathrm{GHG} \text { emissions in metric tons of } \mathrm{CO}_{2} \text { equivalent, independent of any } \mathrm{GHG} \text { trades such as } \\
\text { purchases, sales, or transfers of offsets or allowances }\end{array}$ & & $\mathrm{X}$ & \\
\hline $\begin{array}{l}\text { Report gross other indirect (Scope 3) GHG emissions in metric tons of } \mathrm{CO}_{2} \text {, equivalent, excluding indirect emissions from } \\
\text { the generation of purchased or acquired electricity, heating, cooling, and steam consumed by the organization. Exclude any } \\
\text { GHG trades such as purchases, sales, or transfers of offsets or allowances }\end{array}$ & & & $\mathrm{X}$ \\
\hline Report gases included in the calculation & $\mathrm{X}$ & $\mathrm{X}$ & $\mathrm{X}$ \\
\hline Report biogenic $\mathrm{CO}_{2}$ emissions in metric tons of $\mathrm{CO}_{2}$ equivalent separately from the gross direct (Scope 1) GHG emissions & $\mathrm{X}$ & & \\
\hline Report biogenic $\mathrm{CO}_{2}$ emissions in metric tons of $\mathrm{CO}_{2}$ equivalent separately from the gross indirect (Scope 3) $\mathrm{GHG}$ emissions & & & $\mathrm{X}$ \\
\hline Report other indirect (Scope 3) emissions categories and activities included in the calculation & & & $\mathrm{X}$ \\
\hline $\begin{array}{l}\text { Report the chosen base year, the rationale for choosing the base year, emissions in the base year, and the context for any } \\
\text { significant changes in emissions that triggered recalculations of base year emissions }\end{array}$ & $\mathrm{X}$ & $\mathrm{X}$ & $\mathrm{X}$ \\
\hline Report standards, methodologies, and assumptions use & $\mathrm{X}$ & $\mathrm{X}$ & $\mathrm{X}$ \\
\hline $\begin{array}{l}\text { Report the source of the emissions factors used and the global warming potential (GWP) rates used or a reference to the } \\
\text { GWP source }\end{array}$ & $\mathrm{X}$ & $\mathrm{X}$ & $\mathrm{X}$ \\
\hline Report the chosen consolidation approach for emissions (equity share, financial control, operational control) & $\mathrm{X}$ & $\mathrm{X}$ & \\
\hline \multicolumn{4}{|l|}{ Guidelines for reporting greenhouse gas emission intensity } \\
\hline \multicolumn{4}{|c|}{$\begin{array}{ll}\text { Report the GHG emission intensity ratio } \\
\text { Report the organization-specific metric (the ratio denominator) chosen to calculate the ratio } \\
\text { Report the types of GHG emissions included in the intensity ratio: direct (Scope 1), energy indirect (Scope 2), other indirect (Scope 3) } \\
\text { Report gases included in the calculation }\end{array}$} \\
\hline \multicolumn{4}{|l|}{ Guidelines for reporting on the reduction of greenhouse gas emissions } \\
\hline \multicolumn{4}{|c|}{$\begin{array}{l}\text { Report the amount of } \mathrm{GHG} \text { emission reductions achieved as a direct result of initiatives to reduce emissions, in metric tons of } \mathrm{CO}_{2} \text { equivalent } \\
\text { Report gases included in the calculation (whether } \mathrm{CO}_{2}, \mathrm{CH}_{4}, \mathrm{~N}_{2} \mathrm{O}, \mathrm{HFC}_{s}, \mathrm{PFC}_{s}, \mathrm{NF}_{3}, \mathrm{SF}_{6} \text { or all) } \\
\text { Report the chosen base year or baseline and the rationale for choosing it } \\
\text { Report standards, methodologies, and assumptions used } \\
\text { Report whether the reduction in GHG emissions occurred in Scope 1, Scope } 2 \text { or Scope } 3 \text { emissions }\end{array}$} \\
\hline
\end{tabular}

Source: GRI (2013). 
1.3. Greenhouse gas emissions and reporting thereof. The Carbon Disclosure Project (CDP) is a global disclosure system for companies to report their environmental impacts and strategies to investors (CDP, 2013). Since the establishment of the CDP over ten years ago, the CDP platform has evolved significantly, supporting multinational purchasers to build more sustainable supply chains and it enables cities around the world to exchange information, take best practice action and build climate resilience (CDP, 2013). This initiative assesses the climate performance of companies and drives improvements through shareholder engagement (CDP, 2013).

The traditional view is that the reduction of GHG emissions imposes additional costs on firms (Nishitani and Kokubu, 2012); however, to ensure long-term success in a competitive business environment, companies need to be able to understand and manage their GHG risks and need to be prepared for future national or regional climate change policies and regulations (WRI, 2004). In a study conducted by Nishitani et al. (2012), it was proven that the reduction of GHG emissions is regarded as an intangible value by stockholders and investors and can therefore enhance firm value.

South Africa is ranked as the $7^{\text {th }}$ largest emitter of GHG emissions per capita in the world and, if the South African economy grows without constraints over the next few decades, GHG emissions will continue to escalate, multiplying more than four-fold by mid-century (Winkler, Hughes, Marquard, Haw and Merven, 2011).

If GHG emissions are to be managed, they must first be measured and reported (Association of Certified Chartered Accountants, 2011). The Greenhouse Gas Protocol (GHG Protocol) Initiative is a multistakeholder partnership of businesses, non-government organizations (NGOs), governments and others convened by the World Resource Institute (WRI), a US-based environmental NGO, and the World Business Council for Sustainable Development (WBCSD), a Geneva-based coalition of 170 international companies. The GHG Protocol Initiative comprises two separate but linked standards, namely:

- GHG Protocol Corporate Accounting and Reporting Standard (step-by-step guide for companies to use in quantifying and reporting their GHG emissions).

- GHG Protocol Project Quantification Standard (forthcoming: a guide to quantify reductions from GHG mitigation projects).

The GHG Protocol Initiative encourages the use of the GHG Protocol Corporate Standard by all companies regardless of their experience in preparing a GHG inventory. Taking into consideration possible future regulations regarding GHG emission, significant GHG emissions in a company's value chain may result in increased costs (upstream) or reduced sales (downstream); it therefore makes good business sense to improve one's understanding of the companies' GHG emissions and a method to do so is by compiling a GHG inventory that adheres to the principles of reporting standards of relevance, completeness, consistency, transparency and accuracy. What gets measured gets managed and proper measurement and accounting can contribute to finding the most effective reduction opportunities (ACCA, 2011). GHG emissions can further be classified as direct GHG emissions or indirect GHG emissions. Direct GHG emissions are emissions from sources that are owned or controlled by the company and are principally the result of the following types of activities undertaken by a company (ACCA, 2011):

- Generation of electricity, heat or steam: These emissions result from combustion of fuels in stationary sources such as boilers, furnaces and turbines.

- Physical or chemical processing. Most of these emissions result from the manufacture or processing of chemicals and materials, for example cement, aluminium, acidic acid, ammonia manufacture and waste processing.

- Transportation of materials, products, waste and employees. These emissions result from the combustion of fuels in company-owned/-controlled mobile combustion sources such as trucks, trains, ships, airplanes, buses and cars;

- Fugitive emissions. These emissions result from intentional or unintentional releases, for example equipment leaks from joints, seals, packing and gaskets; methane emissions from coal mines and venting; hydrofluorocarbon (HFC) emissions during the use of refrigeration and airconditioning equipment, and methane leakages from gas transport.

Direct GHG emissions are classified under Scope 1 emissions as per the guidelines and principals of the GHG Protocol. Indirect GHG emissions are emissions that are consequences of the activities of the company, but occur at sources owned or controlled by another company (WRI, 2004). Indirect GHG emissions are classified under Scope 2 and Scope 3 emissions, while Scope 2 emissions account for GHG emissions from the generation of purchased electricity consumed by the company, and Scope 3 emissions allow for the treatment of all other indirect emissions. Credible information on Scope 1 and Scope 2 emissions allows a company to better understand what is happening inside its fences as it provides information on what is hap- 
pening at the plant or factory as well as how much electricity is being bought to keep the plant or factory operating (ACCA, 2011).

Scope 3 emissions look at emissions across the full value chain and research has suggested that Scope 3 emissions could account for approximately 75 percent of an entity's total GHG emissions (ACCA, 2011). Measuring Scope 3 emissions provides information needed to understand climate-related risks and opportunities upstream and downstream from operations, beyond operational boundaries and on the products and services developed and sold and may challenge companies to look at what they are doing and not just how they are doing it (ACCA, 2011). Due to the wide variety of emission sources, calculation methods and lack of consistency of approach in Scope 3 accounting resulted in companies, investors and other stakeholders calling for more standard approaches to accounting. It is important that a public GHG report is based on the best data available at the time of publication and being transparent about the limitations of the data, while all material discrepancies that were previously identified are also reported (WRI, 2004). As per the GHG Protocol Corporate Standard, a GHG emissions report should include the following information:

- A description of the company and inventory boundary.

- An outline of the organizational boundaries chosen, including the chosen consolidation approach.

- An outline of the operational boundaries chosen, and if Scope 3 is included, a list specifying which types of activities are covered.

- The reporting period that is covered.

- Information on emissions.

- Total Scope 1 and Scope 2 emissions independent of any GHG trades such as sales, purchases, transfers or banking of allowances.

- Emissions data separate for each scope.

- Emissions data for all six GHGs separately $\left(\mathrm{CO}_{2}\right.$, $\mathrm{CH}_{4}, \mathrm{~N}_{2} \mathrm{O}, \mathrm{HFCs}$, PFCs, $\mathrm{SF}_{6}$ ). In the accounting and reporting standard amendment of February 2013 , nitrogen difluoride $\left(\mathrm{NF}_{3}\right)$ was added to the list of GHGs (WRI, 2013) and the requirement was changed to emissions data for all GHGs covered by the UNFCCC/Kyoto Protocol separately in metric tons of $\mathrm{CO}_{2}$ equivalent (WRI, 2013). The United National Framework Convention on Climate Change's (UNFCCC) objective is to prevent dangerous human interference with the climate system by stabilizing atmospheric concentrations of GHGs at safe levels (WRI, 2013). The UNFCCC itself set no mandatory limits on GHG emissions for individual countries and contains no enforcement mechanisms, but instead provides for updates ('protocols') that set mandatory emission limits (WRI, 2013). The Kyoto Protocol was adopted in 1997 and came into force in 2005 and set binding GHG emission reduction targets for a group of industrialized countries. These targets are implemented in rolling emission reductions commitment periods, with the first period from 2008 to 2012, and the second from 2013 to 2020 (WRI, 2013).

- Year chosen as base year and emissions profile over that time.

- Appropriate context for any significant emission changes that trigger base year emission recalculation (acquisitions, divestitures, outsourcing etc.).

- Emissions data for direct $\mathrm{CO}_{2}$ emissions from biologically sequestered carbon.

- Methodologies used to calculate or measure emissions, providing a reference or link to any calculation tools used.

- Any specific exclusion of sources, facilities and/or operations.

Ratios can also be used, which might be useful and relevant to the decision-making process and the following examples of ratios for GHG reporting can be considered:

\section{- Productivity/efficiency ratios}

These ratios express the value or achievement of a business divided by its GHG impact. Increasing efficiency ratios reflect a positive performance improvement. Examples of productivity/efficiency ratios include resource productivity (e.g. sales per GHG) and process eco-efficiency (e.g. production volume per amount of GHG).

\section{- Intensity ratios}

These ratios express GHG impact per unit of physical activity or unit of economic output. A physical intensity ratio is suitable when aggregating or comparing across companies that have similar products, while an economic intensity ratio is suitable when aggregating or comparing across companies that produce different products. A declining intensity ratio reflects a positive performance improvement. Intensity ratios include:

- Product emission intensity (e.g. tonnes of $\mathrm{CO}_{2}$ emissions per electricity generated).

- Service intensity (e.g. GHG emissions per function or per service).

- Sales intensity (e.g. emissions per sales).

\section{- Percentages}

This is a ratio between two similar issues. Examples of percentages can be meaningful in performance 
reports, which include current GHG emissions expressed as a percentage of base year GHG emissions.

Reporting climate change activities is important to manage reputation and by telling a positive story may contribute to satisfy stakeholders' needs and their expectations as well as attracting possible new business opportunities to achieve a strategic advantage over competitors by aiming to lead in a low carbon market (CDP, 2012).

\section{Problem investigated and objective}

Although sustainable reporting has grown significantly in the recent years, latest evidence suggests that only 21 percent of listed companies worldwide report any sustainability information (Solomon and Maroun, 2012). In South Africa, government has committed to reduce national GHG emissions by 34 percent by 2020 and 42 percent by 2025 , against the business-as-usual scenario (CDP, 2010). This commitment as well as the introduction of the Green Paper on climate change and the policy on carbon tax sends a clear signal to businesses that the country is entering a regulatory phase to curb GHG emissions (CDP, 2010). In a challenging global environment and the ever-increasing focus on environmental performance, it is imperative for financial managers and environmental managers to understand both the risk and financial implication associated with poor or reactive environmental management as well as the economic imperatives that determine the viability of a corporation. The objective of this paper is to investigate to which extent the top-ten manufacturing companies listed on the JSE adhere to good disclosure practices, specifically regarding the disclosure of carbon emissions.

\section{Research method}

Content analysis is a mixed method research technique that can be described as the scientific study of the content with reference to the meanings, context and intentions contained in messages (Prasad, 2009). Understanding the textual information in corporate disclosures is important for financial accounting research $(\mathrm{Li}, 2010)$ and the nature of accountants is to want to monitor trends (Olalere, 2012). In this research, a manual content analysis approach was applied to study the integrated reports, specifically focusing on sustainability reporting regarding emissions. As content analysis is generally applied to narrative text such as political speeches, transcribed interviews and published literature and seeks to elucidate what can be learned about the authors' or respondents' understanding of phenomena and terminology (Trace, 2001), it is regarded as the most suitable technique for this research. The advantage of applying a content analysis approach is that the study analyzes all the disclosures in the reports instead of merely looking for the presence of the particular item. A disadvantage is the fact that the cost associated with manually collecting data is high and therefore most studies have small sample sizes that may limit the scope of the empirical test ( $\mathrm{Li}, 2010)$. The measuring instrument that was used is a checklist containing statements and questions that were formulated by combining the guidelines provided by various sources as studied in the literature review. Sources used are King III, GRI, GHG Protocol, and Carbon disclosure project with the specific focus on the reporting of emissions. The high level overview guidelines of each source are summarized in Table 2 below.

Table 2. Summary of emissions reporting guidelines per source studied

\begin{tabular}{|c|c|}
\hline Source & Summarized overview guidelines \\
\hline King III & $\begin{array}{l}\text { Complete; timely; relevant; accurate; honest; } \\
\text { accessible and comparable with past performance } \\
\text { Report on the impact of operations on stake- } \\
\text { holders } \\
\text { Report on economic, social and environmental } \\
\text { issues } \\
\quad \begin{array}{l}\text { Reports should be assured and name of assurer } \\
\text { should be disclosed }\end{array}\end{array}$ \\
\hline GRI & $\begin{array}{l}\text { Report on chosen 'in accordance' option } \\
\text { Report per guidelines on economic, environmental } \\
\text { and social categories } \\
\text { Report per guidelines for emissions disclosure as } \\
\text { part of the environmental category per Scope } 1 \text {, } \\
\text { Scope } 2 \text { and Scope } 3 \text { emissions }\end{array}$ \\
\hline GHG Protocol & $\begin{array}{l}\text { Description of the company and inventory bound- } \\
\text { ary and the reporting period that is covered } \\
\text { Emissions data separately for Scope 1, Scope } 2 \\
\text { and Scope } 3 \\
\text { Emissions data for all GHGs separately } \\
\text { Productivity/efficiency ratios } \\
\text { Intensity ratios }\end{array}$ \\
\hline
\end{tabular}

The annual integrated and sustainability reports were analyzed and evaluated against the checklist to reach an outcome regarding the level of adherence to the recommendations and guidelines. Reliability of the data was ensured by applying a systematic and methodical analysis of the data; therefore, the study utilized a formal procedure building on the checklist that was created through the literature review.

The top companies based on market capitalization were selected using the JSE Top 40 Index. The top 40 companies represent over $80 \%$ of the total market capitalization for all JSE-listed companies. From the top 40-listed companies, the top-ten manufacturing companies were selected. This selection of manufacturing companies was based on the following definition of manufacturing companies: "a business venture which deals with the process of converting raw materials into finished products through a manufac- 
turing process" (Garetti et al., 2012). The selection was further verified by two external market analysts for confirmation. The reason for selecting this sample is primarily because manufacturing companies in general contributed the most towards the recorded emissions and it can be considered valuable for those companies to effectively report such emissions with the aim to inform all shareholders and stakeholders and at the same time reassure them of their commitment towards reducing emissions and mitigate climate change, while realizing the importance of reporting such information. The information was obtained by locating and analyzing the integrated and sustainability reports relating to the 2013 financial year of all these companies. The following companies were identified as the top-ten manufacturing companies that form part of the JSE top 40.

Table 3. Top 10 listed manufacturing companies

\begin{tabular}{|c|c|c|}
\hline 1. & $\begin{array}{l}\text { British } \\
\text { American } \\
\text { Tobacco }\end{array}$ & $\begin{array}{l}\text { Holding company for a group of companies that manu- } \\
\text { facture, market and sell cigarettes and other tobacco } \\
\text { products, including cigars and roll-your-own tobacco. } \\
\text { The world's second-largest tobacco company by sales. } \\
\text { BAT has a market leading position in over } 50 \text { countries } \\
\text { and operations in approximately } 180 \text { countries. }\end{array}$ \\
\hline 2. & SAB Miller & $\begin{array}{l}\text { Multinational brewing and beverage company head- } \\
\text { quartered in London, United Kingdom. The second } \\
\text { largest brewer and major bottler of Coca-Cola. }\end{array}$ \\
\hline 3. & Richemont & $\begin{array}{l}\text { Designs, manufactures, distribute and sell premium } \\
\text { jewellery, watches, leather goods, writing instruments, } \\
\text { shotguns, rifles, clothing and accessories. Richemont } \\
\text { is the third-largest luxury goods company in the world. }\end{array}$ \\
\hline 4. & Sasol & $\begin{array}{l}\text { Integrated oil and gas company with substantial } \\
\text { chemical interest, with production facilities located in } \\
\text { South Africa, Europe, North America and Asia. The } \\
\text { company operates commercial scale facilities to } \\
\text { produce fuels and chemicals from coal in South Africa } \\
\text { and is developing ventures internationally to convert } \\
\text { natural gas into clean diesel fuel. }\end{array}$ \\
\hline 5. & Aspen & $\begin{array}{l}\text { A global supplier of branded and generic pharmaceuti- } \\
\text { cals and of consumer and nutritional products in } \\
\text { selected territories. }\end{array}$ \\
\hline 6. & Bidvest & $\begin{array}{l}\text { Holding company for a group of companies operating } \\
\text { in a range of sectors. Subsidiaries manufacture and } \\
\text { distribute food and allied products to the catering } \\
\text { industry, as well as packaging, stapling, fastening and } \\
\text { adhesive tapes, office products, cosmetics, toiletries } \\
\text { and skincare products. They also supply cleansing } \\
\text { products and provide laundering services. }\end{array}$ \\
\hline 7. & $\begin{array}{l}\text { Tiger } \\
\text { Brands }\end{array}$ & $\begin{array}{l}\text { Manufactures, processes and distributes food products } \\
\text { that include milling and baking confectioneries, general } \\
\text { foods, edible oils and derivatives. }\end{array}$ \\
\hline 8. & Nampak & $\begin{array}{l}\text { Africa's largest packaging company that participates in } \\
\text { extensive recycling initiatives and invest significant } \\
\text { time and resources into the development of more } \\
\text { sustainable products. }\end{array}$ \\
\hline 9. & Steinhoff & $\begin{array}{l}\text { Holding company for a group of companies that } \\
\text { manufacture and distribute household goods and } \\
\text { related timber products throughout Southern Africa } \\
\text { and Europe. The group markets its products to middle } \\
\text { and upper income groups. }\end{array}$ \\
\hline 10. & Mondi Ltd & $\begin{array}{l}\text { Principally involved in the manufacture of packaging } \\
\text { paper, converted packaging products and uncoated } \\
\text { fine paper. }\end{array}$ \\
\hline
\end{tabular}

\section{Research results}

4.1. Overall results. The checklist consists of eighteen (18) close questions. A 'yes' answer on the checklist indicates that the specific company does report on the specific item listed. The number of 'yes' answers were counted and expressed as a percentage of the total questions on the checklist. A percentage was allocated to each company reviewed and achieving a percentage of less than $25 \%$ was regarded as minimal emissions reporting. Achieving a percentage between 25 and 50 was classified as overview emissions reporting and a percentage between 51 and 80 was classified as detailed emissions reporting. Companies achieving more than 81 percent, therefore the number of yes answers expressed as a percentage of total questions, were classified as companies that do comprehensive emissions reporting. The companies were given a score from 1 to 4 based on the level of classification achieved as per the process described above. Achieving a number1 represents minimal emissions reporting, while a 4 represents comprehensive emissions reporting. Table 4 below provides a summary of the percentages achieved and classification of the companies.

Table 4. Scores and classification of results

\begin{tabular}{|c|c|l|c|}
\hline $\begin{array}{c}\text { Number of } \\
\text { questions with } \\
\text { 'yes' answers }\end{array}$ & $\begin{array}{c}\text { Number of 'yes' } \\
\text { answers as a \% } \\
\text { of total answers }\end{array}$ & $\begin{array}{c}\text { Observed level of } \\
\text { emissions reporting }\end{array}$ & Score \\
\hline $\begin{array}{c}\text { Equal or less } \\
\text { than } 4\end{array}$ & $<=25 \%$ & Minimal & 1 \\
\hline 5 to 9 & $25-50 \%$ & Overview & 2 \\
\hline 10 to 14 & $51-80 \%$ & Detailed & 3 \\
\hline More than 15 & $81-100 \%$ & Comprehensive & 4 \\
\hline
\end{tabular}

Seven out of the eighteen questions were more narrative information as reported in the integrated reports and eleven questions were based on more quantifiable data. Table 5 provides a summary of the results achieved expressed in percentages by the different companies, both for the qualitative, more narrative type of questions as well as for the quantitative, more computable questions and then the overall results calculated on 18 questions.

Table 5. Scores per type of question and average in total

\begin{tabular}{|l|c|c|c|}
\hline $\begin{array}{c}\text { Company } \\
\text { name }\end{array}$ & $\begin{array}{c}\text { Score on } \\
\text { narrative } \\
\text { questions } \\
\text { asked (7) }\end{array}$ & $\begin{array}{c}\text { Score on com- } \\
\text { putable questions } \\
\text { asked (11) }\end{array}$ & $\begin{array}{c}\text { Average overall } \\
\text { score on } \\
\text { total questions } \\
\text { asked (18) }\end{array}$ \\
\hline Nampak & (7) $100 \%$ & (8) $73 \%$ & $(15) 83 \%$ \\
\hline Bidvest & (7) $100 \%$ & (9) $82 \%$ & (16) $89 \%$ \\
\hline Mondi & (7) $100 \%$ & (7) $63 \%$ & (14) $77 \%$ \\
\hline BAT & (7) $100 \%$ & (4) $36 \%$ & (11) $61 \%$ \\
\hline Tiger Brands & (7) $100 \%$ & (5) $45 \%$ & (12) $67 \%$ \\
\hline Richemont & (7) $100 \%$ & (6) $55 \%$ & (13) $72 \%$ \\
\hline Sasol & (7) $100 \%$ & (4) $36 \%$ & (11) $61 \%$ \\
\hline
\end{tabular}


Table 5 (cont.). Scores per type of question and average in total

\begin{tabular}{|l|c|c|c|}
\hline $\begin{array}{c}\text { Company } \\
\text { name }\end{array}$ & $\begin{array}{c}\text { Score on } \\
\text { narrative } \\
\text { questions } \\
\text { asked (7) }\end{array}$ & $\begin{array}{c}\text { Score on com- } \\
\text { putable questions } \\
\text { asked (11) }\end{array}$ & $\begin{array}{c}\text { Average overall } \\
\text { score on } \\
\text { total questions } \\
\text { asked (18) }\end{array}$ \\
\hline Steinhoff & (5) $71 \%$ & (3) $27 \%$ & (8) $44 \%$ \\
\hline Aspen & (6) $86 \%$ & (2) $18 \%$ & (8) $44 \%$ \\
\hline SAB Miller & (4) $57 \%$ & (4) $36 \%$ & (8) $44 \%$ \\
\hline
\end{tabular}

None of the companies that were analyzed, were classified in the category of minimal emissions reporting; therefore, none of them achieve a percentage of less than 25. Steinhoff, Aspen and SAB Milleronly had eight 'yes' answers on the checklist and achieved a percentage of 44 percent respectively. These companies were classified as companies that do overview emissions reporting and score a point 2 as per Table 4 . Companies that achieved a percentage of between 51 and $80 \%$ were classified as companies that perform more detailed emissions reporting and score a 3 as per Table 4. Five of the companies reviewed fall into this category by having between ten and fourteen 'yes' answers on the checklist. These companies are British American Tabaco (BAT), Tiger Brands, Richemont, Mondi and Sasol. Nampak and Bidvest were the only two companies with more than 15 'yes' answers and achieved more than 81 percent and are therefore classified as companies that do comprehensive emissions reporting and a score of 4 as per Table 4. Based on the scores calculated, Bidvest has performed the best and Steinhoff, Aspen and SAB Miller the worst in terms of the questions specifically related to this study.

The majority of the companies reviewed are scored at level 3, which indicates detailed emissions reporting based on the questions used in this study. All the companies that scored at level 4 utilize the GHG Protocol as guideline, even though the averages relating to the different guidelines used are very close. Figure 1 provides a graphical representation of the scores per guideline used.

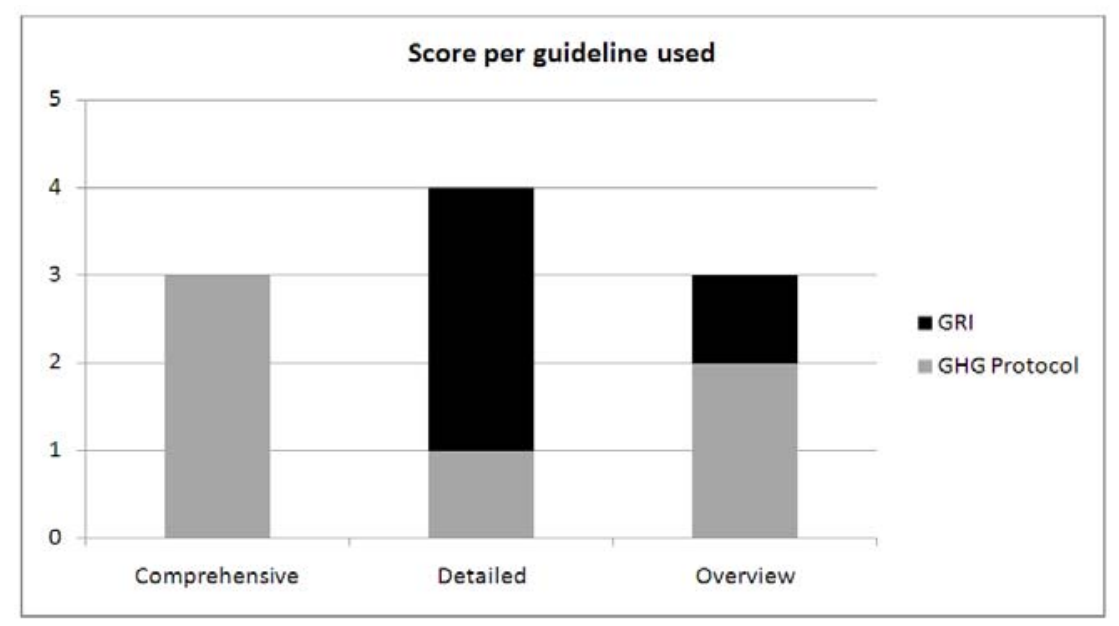

Fig. 1. Score per guideline

4.2. Results on narrative reporting. The questions on the checklist were broken down into narrative, more qualitative types of disclosure and more performance- related, quantitative types of disclosures. Table 6 provides a summary of the results of seven narrative questions that were tested using the compiled checklist.

Table 6. Summary of results on narrative questions tested

\begin{tabular}{|c|c|c|c|c|c|c|c|c|c|c|c|}
\hline & Nampak & Bidvest & $\begin{array}{l}\text { Mondi } \\
\text { Ltd }\end{array}$ & BAT & $\begin{array}{l}\text { Tiger } \\
\text { Brands }\end{array}$ & $\begin{array}{l}\text { Riche } \\
\text { mont }\end{array}$ & Sasol & $\begin{array}{c}\text { Stein- } \\
\text { hoff }\end{array}$ & Aspen & $\begin{array}{l}\text { SAB } \\
\text { Miller }\end{array}$ & Amount \\
\hline Environmental policy in place & $\checkmark$ & $\checkmark$ & $\checkmark$ & $\checkmark$ & $\checkmark$ & $\checkmark$ & $\checkmark$ & $\checkmark$ & $\checkmark$ & $\checkmark$ & 10 \\
\hline $\begin{array}{l}\text { Environmental system to monitor } \\
\text { emissions }\end{array}$ & $\checkmark$ & $\checkmark$ & $\checkmark$ & $\checkmark$ & $\checkmark$ & $\checkmark$ & $\checkmark$ & $\checkmark$ & $\checkmark$ & $\mathbf{x}$ & 9 \\
\hline $\begin{array}{l}\text { Report on targets to reduce } \\
\text { emissions }\end{array}$ & $\checkmark$ & $\checkmark$ & $\checkmark$ & $\checkmark$ & $\checkmark$ & $\checkmark$ & $\checkmark$ & $x$ & $x$ & $x$ & 7 \\
\hline Report on changes in emissions & $\checkmark$ & $\checkmark$ & $\checkmark$ & $\checkmark$ & $\checkmark$ & $\checkmark$ & $\checkmark$ & $x$ & $\checkmark$ & $\checkmark$ & 9 \\
\hline Report on specific guidelines used & $\checkmark$ & $\checkmark$ & $\checkmark$ & $\checkmark$ & $\checkmark$ & $\checkmark$ & $\checkmark$ & $\checkmark$ & $\checkmark$ & $\checkmark$ & 10 \\
\hline GHG Protocol & $\checkmark$ & $\checkmark$ & $\checkmark$ & & & $\checkmark$ & & $\checkmark$ & & $\checkmark$ & 6 \\
\hline GRI & & & & $\checkmark$ & $\checkmark$ & & & & $\checkmark$ & & 4 \\
\hline CDP participation & $\checkmark$ & $\checkmark$ & $\checkmark$ & $\checkmark$ & $\checkmark$ & $\checkmark$ & $\checkmark$ & $\checkmark$ & $\checkmark$ & $\checkmark$ & 10 \\
\hline $\begin{array}{l}\text { Report on risks and opportunities } \\
\text { for climate change mitigation }\end{array}$ & $\checkmark$ & $\checkmark$ & $\checkmark$ & $\checkmark$ & $\checkmark$ & $\checkmark$ & $\checkmark$ & $\checkmark$ & $\checkmark$ & $x$ & 9 \\
\hline Amount & 7 & 7 & 7 & 7 & 7 & 7 & 7 & 5 & 6 & 4 & \\
\hline
\end{tabular}


As 100 percent of the companies do report on an environmental policy it is evident that all the companies are aware of the importance of environmental matters as well as the criticality of the management and control thereof. Of the companies reviewed, 90 percent report on a system to monitor emissions, and environmental awareness is further confirmed as 70 percent of the sample companies report on specific targets to reduce or improve on their current level of emissions.
Changes in the level of emissions as well as the reasons for these changes are reported by nine out of the ten companies reviewed. All the top-ten manufacturing companies reviewed made use of guidelines when reporting on their emissions of which sixty percent of the companies used the GHG Protocol and the remainder of the companies used the guidelines provided by the GRI. All the companies reviewed did participate in the CDP in 2013 as indicated on Fig. 2.

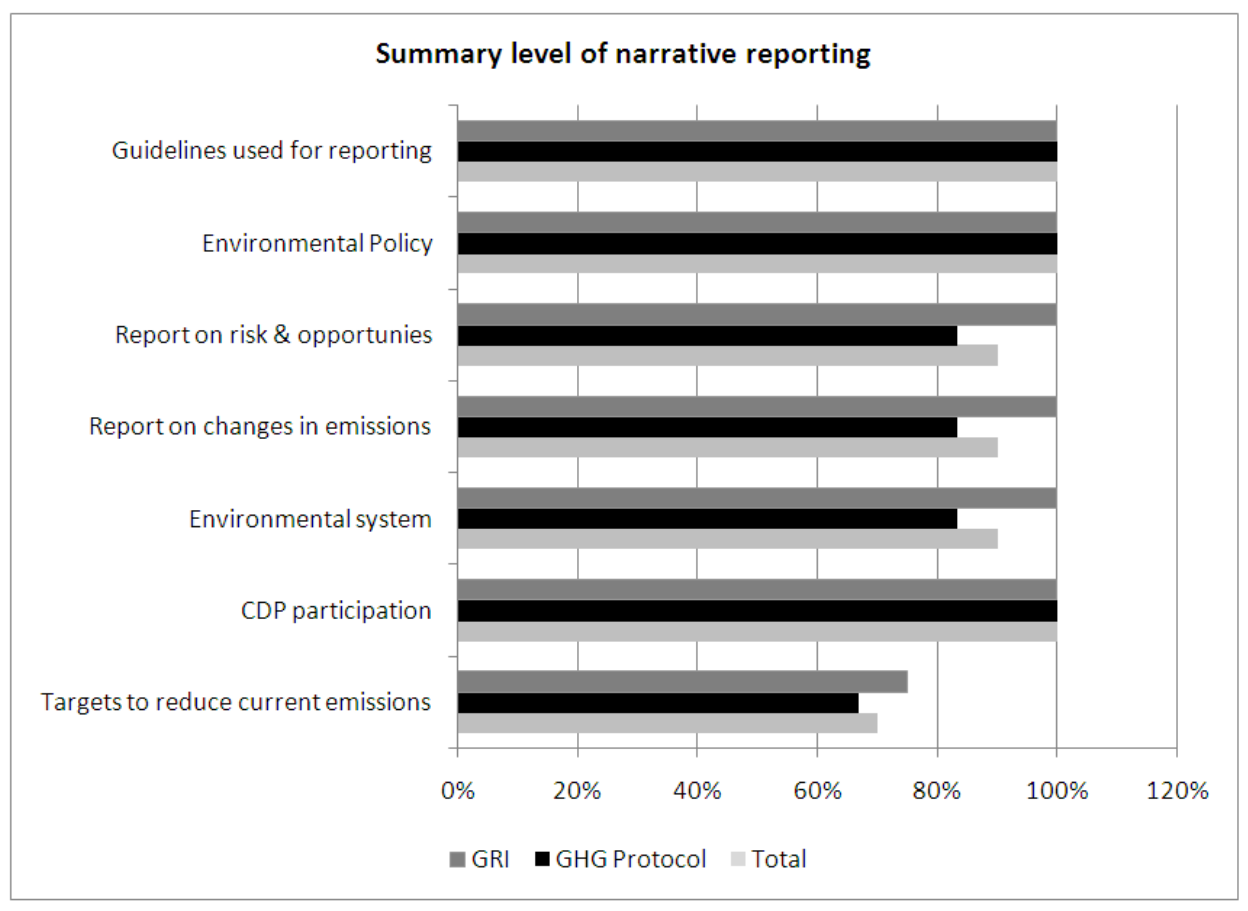

Fig. 2. Level of narrative reporting in total and per guideline used

4.3. Results on quantitative emissions reporting. eleven questions on the checklist that relate to the Table 7 provides a summary of the results of the qualitative more computable emissions reporting.

Table 7. Summary of results on questions relating to quantitative, computable emissions reporting

\begin{tabular}{|c|c|c|c|c|c|c|c|c|c|c|c|}
\hline & Nampak & Bidvest & $\begin{array}{l}\text { Mondi } \\
\text { Ltd }\end{array}$ & BAT & $\begin{array}{l}\text { Tiger } \\
\text { Brands }\end{array}$ & $\begin{array}{l}\text { Riche } \\
\text { mont }\end{array}$ & Sasol & $\begin{array}{l}\text { Stein- } \\
\text { hoff }\end{array}$ & $\begin{array}{l}\text { As- } \\
\text { pen }\end{array}$ & $\begin{array}{l}\text { SAB } \\
\text { Miller }\end{array}$ & Amount \\
\hline Report on Scope 1 emissions & $\checkmark$ & $\checkmark$ & $\checkmark$ & $\checkmark$ & $\checkmark$ & $\checkmark$ & $\checkmark$ & $\checkmark$ & $\checkmark$ & $\checkmark$ & 10 \\
\hline Report on Scope 2 emissions & $\checkmark$ & $\checkmark$ & $\checkmark$ & $\checkmark$ & $\checkmark$ & $\checkmark$ & $\checkmark$ & $\checkmark$ & $\checkmark$ & $\checkmark$ & 10 \\
\hline Report on Scope 3 emissions & $\checkmark$ & $\checkmark$ & $\checkmark$ & $x$ & $\checkmark$ & $\checkmark$ & $x$ & $x$ & $x$ & $x$ & 5 \\
\hline $\begin{array}{l}\text { Include a list of Scope } 3 \\
\text { emissions }\end{array}$ & $\checkmark$ & $\checkmark$ & $\checkmark$ & $x$ & $x$ & $\checkmark$ & $x$ & $x$ & $x$ & $x$ & 4 \\
\hline Report on total emissions & $\checkmark$ & $\checkmark$ & $\checkmark$ & $\checkmark$ & $\checkmark$ & $\checkmark$ & $\checkmark$ & $\checkmark$ & $x$ & $\checkmark$ & 9 \\
\hline $\begin{array}{l}\text { Report on tons of } \mathrm{CO}_{2} \text { per unit } \\
\text { of production }\end{array}$ & $\checkmark$ & $\checkmark$ & $\checkmark$ & $\checkmark$ & $\checkmark$ & $x$ & $\checkmark$ & $x$ & $x$ & $\checkmark$ & 7 \\
\hline $\begin{array}{l}\text { Report emissions intensity } \\
\text { FTE }\end{array}$ & $\checkmark$ & $\checkmark$ & $x$ & $x$ & $x$ & $\checkmark$ & $x$ & $x$ & $x$ & $x$ & 3 \\
\hline $\begin{array}{l}\text { Report emissions per sales or } \\
\text { revenue }\end{array}$ & $\checkmark$ & $\checkmark$ & $x$ & $x$ & $x$ & $x$ & $x$ & $x$ & $x$ & $x$ & 2 \\
\hline $\begin{array}{l}\text { Report on production volume } \\
\text { per amount of GHG emissions }\end{array}$ & $x$ & $x$ & $x$ & $x$ & $x$ & $x$ & $x$ & $x$ & $x$ & $x$ & - \\
\hline $\begin{array}{l}\text { Report the types of GHG } \\
\text { emissions included in the } \\
\text { intensity ratios }\end{array}$ & $x$ & $\checkmark$ & $x$ & $x$ & $x$ & $x$ & $x$ & $x$ & $x$ & $x$ & 1 \\
\hline $\begin{array}{l}\text { Report emissions data for all } \\
\text { seven GHGs separately }\end{array}$ & $x$ & $x$ & $\checkmark$ & $x$ & $x$ & $x$ & $x$ & $x$ & $x$ & $x$ & 1 \\
\hline Amount & 8 & 9 & 7 & 4 & 5 & 6 & 4 & 3 & 2 & 4 & \\
\hline
\end{tabular}


All of the top-ten manufacturing companies listed on the JSE reported on Scope 1 and Scope 2 emissions separately in 2013. Scope 1 emissions are direct GHG emissions from sources owned or controlled by the company and are principally the result of various activities undertaken by a company, and Scope 2 emissions account for indirect GHG emissions from the generation of purchased electricity consumed by the company. Only half (5) of the companies reported on Scope 3 emissions. Scope 3 emissions are all the other indirect GHG emissions that do not form part of Scope 2 emissions. From all the companies that reported Scope 3 emissions, 80 percent (4) did include a list of activities that are included in the Scope 3 emissions reporting. These activities mainly consist of activities such as business travel in commercial airlines, car rentals, employee commuting, transportation of raw materials and other products, business travel and hotel accommodation and the consumption of office paper.

Intensity ratios express the GHG impact per unit of physical activity or unit of economic output and a declining intensity ratio reflects a positive performance improvement. Both the GRI as well as the GHG Protocol recommend intensity ratios to be included in the reports. From the companies reviewed, 70 percent reported on the intensity level per unit of production, but only two companies (Nampak and Bidvest) reported on more than one intensity ratio. Both these companies reported on the intensity level per FTE as well as the intensity level per sales or revenue. Only 20 percent of companies report on the intensity ratio that measures emissions per revenue or sales. Greenhouse gas consists of seven different gases and reporting requirements indicate reporting on all seven gases separately. In the integrated reports reviewed, very limited information on the list of greenhouse gases were present and only one of the companies reviewed, reported on all the greenhouse gases separately.

\section{Conclusions}

The results of the empirical research clearly indicate that the companies in the sample selected are aware of the requirements of emissions reporting as the entire sample made use of guidelines and all of them did participate in the CDP in 2013. Even though emissions reporting was present in all the integrated reports for 2013 that were reviewed, the level of detail included is, however, limited and the average percentage of questions with 'yes' answers is $48 \%$. As per the results as summarized in Table 5, it is clear that most companies report in more detail on the narrative sections of emissions reporting. The South African government published their Carbon Tax Policy Paper on 2 May 2013 with the aim of reducing GHG emissions as well as to facilitate the transition to a greener economy. As many investors raised concerns regarding the sustainability of their investments should Carbon Tax be implemented in South Africa, it is important for companies to ensure that the detail of their emissions reporting provide sufficient information for investors to make informed decisions regarding the risk associated with their investments. With the worldwide focus on climate change and actions to mitigate climate change, reporting on emissions might become mandatory in the near future and it is advisable for all companies, but especially for the top manufacturing companies, to improve on their current level of emissions reporting and familiarise themselves with the methods and calculations as per the guidelines to minimize the possible impact on the company.

In the research conducted by Clarkson, Li, Richardson and Vasvari (2011), it was proven that companies that experienced significant declines in environmental performance tend to experience relative declines in their financial resources and/or management capabilities immediately prior to their relative decline in environmental performance. Through efficient and effective environmental reporting, management and stakeholders can be timeously informed of possible environmental areas of concern. With the looming implementation of carbon tax in South Africa, companies should adhere to sustainability reporting as many investors raised concerns regarding the sustainability of their investments should carbon tax be implemented. The proper disclosure of current carbon emissions can make a valuable contribution to investors in the estimation of the possible impact of carbon tax as well as in their investment decision-making. Although the topten manufacturing companies that were studied do report on emissions and on actions to improve the level of emissions, it is recommended to improve on the level of detail that is reported, especially with regard to the more quantifiable data and intensity ratios. Reporting on more specific targets to be achieved in a given timeline might create a strong impression of commitment towards mitigating climate change and it is also recommended for companies to not report targets in general, but to add specific figures and timelines to the target. It is furthermore recommended to improve reporting on the types (scope) of greenhouse gases included in the ratios and on clarifying what gases from the six greenhouse gases are included in the reporting.

\section{Recommendations for future research}

A very limited sample was selected and it is recommended to increase the sample in future research. The checklist compiled includes a limited number of questions and focuses more on the overview of emissions reporting. It is recommended for future research to focus on a specific type of emissions, for example Scope 1, and to 
conduct a similar study focusing only on that type of emissions and the level and detail of reporting on it. There is very limited reporting and informa- tion available from companies on Scope 3 emissions and a study specifically focusing on Scope 3 emissions and the reporting thereof can be valuable.

\section{References}

1. Alton, T., Arndt, C., Davies, R., Hartley, F., Makrelov, K., Thurlow, J. \& Ubogu, D. (2013). Introducing carbon taxes in South Africa, Applied Energy, 116, pp. 344-354.

2. Al-Tuwaijri, S.A., Christensen, T.E. \& Hughes II, K.E. (2004). The relations among environmental disclosure, environmental performance, and economic performance: A simultaneous equations approach, Accounting, Organizations and Society, 29, pp. 47-471.

3. Association of Chartered Certified Accountants (ACCA). (2011). The carbon we're not counting. Accounting for scope 3 carbon emissions, 26 p. April.

4. Carbon Disclosure Project (CDP). (2010). Carbon Disclosure Project South Africa JSE 100. [Online] Available: https://www.cdproject.net/en-US/Results/Pages/All-investor-Reports.aspx. Accessed: 20 February 2014.

5. Carbon Disclosure Project (CDP). (2012). CDP FTSE 350 Climate Change Report. [Online] Available: https://www.cdproject.net/en-US/Results/Pages/All-investor-Reports.aspx. Accessed: 20 February 2014.

6. Carbon Disclosure Project (CDP). (2013). CDP South Africa 100 Climate Change Report 2013. [Online] Available: https://www.cdproject.net/en-US/Results/Pages/All-investor-Reports.aspx. Accessed: 20 February 2014.

7. Clarkson, P.M., Li, Y., Richardson, G.D. and Vasvari, F.P. (2011). Does it really pay to be green? Determinants and consequences of proactive environmental strategies, Public Policy, 30, pp. 122-144.

8. De Beer, P. and Friend, F. (2006). Environmental accounting: A management tool for enhancing corporate environmental and economic performance, Ecological Economics, 58, pp. 548-560.

9. Devarajan, S., Go, D.S., Robinson, S. and Thierfelder, K. (2009). Tax policy to reduce carbon emissions in South Africa. Policy Research working paper. The World Bank.

10. Eccles, R.G. and Saltzman, D. (2011). Achieving sustainability through integrated reporting, Stanford Social Innovation Review, pp. 57-61.

11. Garetti, M., and Taisch, M. (2012). Sustainable manufacturing: Trends and research challenges, Production Planning \& Control: The Management of Operations, 23 (2-3), pp. 83-104.

12. Garetti, M., Mummolo, G. and Taisch, M. (2012). Special issue on "sustainable manufacturing", Production Planning \& Control: The Management of Operations, 23(2-3), pp. 79-82.

13. Global Reporting Initiative (GRI). (2013). G4 Sustainability Reporting Guidelines. 92 p.

14. Integrated Reporting Committee (IRC). (2011). Framework for integrated reporting and the integrated report: Discussion paper: pp. 1-25, 25 January. Available at: http://www.sustainabilitysa.org. Date of access: 2 April 2014.

15. Jeffrey, R. (2013). Renewables and carbon tax: A negative impact on mining and economic growth, Inside Mining, 9, pp. 18-20.

16. Klausbruckner, C., Annegarn, H., Henneman, L.R.F., and Rafaj, P. (2016). A policy review of synergies and trade-offs in South Africa climate change mitigation and air pollution control strategies, Environmental Science \& Policy, 57, pp. 70-78.

17. Kim, Y. and Worrel, E. (2002). International comparison of $\mathrm{CO}_{2}$ emission trends in the iron and steel industry, Energy Policy, 30, pp. 827-838.

18. Knox-Hayes, J. \& Levy, D. (2011). The politics of carbon disclosure as climate governance, Strategic Organization, 9(1), pp. 1-9.

19. Li, F. (2010). Textual analysis of corporate disclosures: A survey of the literature, Journal of Accounting Literature, 29, pp. 143-165.

20. Mbadlanyana, T. (2013). The political economy of carbon tax in South Africa, Africa Insight, 43(1), pp. 77-90.

21. Nishitani, K. and Kokubu, K. (2012). Why does the reduction of greenhouse gas emissions enhance firm value? The case of Japanese manufacturing firms, Business Strategy and Environment, 21, pp. 517-529.

22. Prasad, B.D. (2009). Content analysis: A method in Social Science research, Research Methods for Social Work, pp. 1-20.

23. Smith, E.E. and Perks, S. (2010). A perceptual study of the impact of green practice implementation on the business functions, South African Business Review, 14(3), pp. 1-29.

24. Solomon, J. and Maroun, W. (2012). Integrated reporting: The influence of King III on social, ethical and environmental reporting, Association of Certified Chartered Accountants, August.

25. Trace, C. (2001). Applying content analysis to case study data: A preliminary report, International Research on Permanent Authentic Records in Electronic Systems, pp. 1-13. June.

26. Winkler, H., Hughes, A., Marquard, A., Haw, M. and Merven, B. (2011). South Africa's greenhouse gas emissions under business-as-usual: The technical basis of 'growth without constraints' in the long-term mitigation scenarios, Energy Policy, 39, pp. 5818-5828.

27. World Resource Institute. (WRI). (2004). The Greenhouse Gas Protocol: A corporate accounting and reporting standard. Revised Edition, 104 p., March.

28. World Resource Institute. (WRI). (2013). The Greenhouse Gas Protocol: Required Greenhouse Gases in Inventories: Accounting and reporting standard amendment, 9 p., March. 